\title{
A note on the nutritional value of enzymatically hydrolyzed feather meal for broiler chickens
}

\author{
A. Rutkowski, D. Józefiak, M. Frątczak and M. Wiąz \\ August Cieszkowski Agricultural University, \\ Department of Animal Nutrition and Feed Management \\ Wotyńska 33, 60-637 Poznań, Poland
}

(Received 28 January 2002; revised version 21 January 2003; accepted 4 April 2003)

\begin{abstract}
Three groups of broiler cockerels, 96 birds each, were kept in cages ( 8 birds each). Diets containing autoclaved feather meal (F), autoclaved and enzymatically hydrolyzed feather meal (FE), and meat-and-bone meal (MBM- control) were fed ad libitum for six weeks. Crude protein of feather meals or MBM made up $14 \%$ of the crude protein in Starter and Grower, and approximately $16 \%$ in Finisher diets. In the first two weeks of life broilers fed diets F and FE had worse performance $(\mathrm{P} \leq 0.05)$ than the control group. At six weeks of life, mean body weight was $2032 \mathrm{~g}$ and feed conversion ratio $1.8 \mathrm{~kg} / \mathrm{kg}$; there were no significant differences between groups. Feeding diets containing FE had no effect on performance, however, the in vitro digestibility of crude protein was better than that of autoclaved feather meal.
\end{abstract}

KEY WORDS: enzymatic hydrolyzis, feather meal, broiler chicken

\section{INTRODUCTION}

The centralization of poultry processing has intensified the problem of disposal of poultry wastes that might pose a serious environmental problem (Patterson et al., 1994). Feathers constitute approximately $10 \%$ of broiler chicken slaughter weight and their inclusion in by-product meal considerably worsens the meal's nutritional value for poultry (Webster et al., 1996). This is why it has been suggested to process feathers separately from other poultry by-products. Feather meals have been used in broiler chicken nutrition for many years (Bhargava et al., 1974; Haque et al., 1991; Patterson et al., 1994; Kim et al., 2002). 
Autoclaving is the most common process in feather disposal, however, the final products are still of questionable quality from the point of view of nutritional requirements of broiler chickens. To improve the nutritional value of feather meals, many other processes have been used as well, including extrusion (Haque et al., 1991; Patterson et al., 1994) and alkali treatment (Moran et al., 1966). Data about the use of autoclaving in combination with enzymatic hydrolyzis is limited. Therefore the objective of our work was to investigate the use of enzymatically hydrolyzed and autoclaved feathers in broiler chicken nutrition.

\section{MATERIAL AND METHODS}

\section{Processing of feather meals}

Two feather meals were used in the experiment: autoclaved (F) and autoclaved and treated by a commercial enzyme complex-Insta Pro ${ }^{\circledR}(\mathrm{FE})$.

Feather meal $\mathrm{F}$ was obtained as follows: feathers were loaded into an autoclave previously heated to $80-100^{\circ} \mathrm{C}$. After $2.5 \mathrm{~h}$ more feathers were loaded and the temperature in the autoclave was raised to $130^{\circ} \mathrm{C}$, and the pressure to $2.5-2.6$ atmospheres; feathers were treated for 15 min under these conditions. Then for $20 \mathrm{~min}$ the temperature was decreased to $107^{\circ} \mathrm{C}$ and the pressure was raised to 6 atmospheres. Under these conditions the feathers were dried for $6 \mathrm{~h}$. During the processing the feathers were subjected to continuous mechanical disintegration, which positively affected the working capacity of the autoclave.

To obtain enzymatically degraded feather meal FE, feather meal $\mathrm{F}$ was mixed with water (1:1), and $2.5 \mathrm{~g} / \mathrm{kg}$ of the enzymatic preparation Insta-Pro ${ }^{\circledR}$ were added. The preparation was based on the following enzymes: proteases, lipases, amylases and a dry post-fermentation extract of Bacillus sp. FE was hydrolyzed for $9 \mathrm{~h}$, then dried for $6 \mathrm{~h}$ at $50^{\circ} \mathrm{C}$, in a Miltenz ${ }^{\mathrm{TM}}$ Millbank Technology ring dryer.

Both feather meals were tested microbiologically for the presence of the following bacterial species: Salmonella, Staphylococcus, pathogenic Streptococcus and Clostridium. The chemical compositions of both feather meals and in vitro digestibility of crude protein were determined according to AOAC (1997), using a T 339 Amino Acid Analyzer (Mikrotechna Praha) to determine amino acid content.

\section{Animals and diets}

The experiment was performed on 288 one-day-old cockerels, Cobb 500, divided randomly into three experimental groups of 96 cockerels each. The birds were kept in cages, by 8 , each cage was treated as a replicate. Three isoprotein and isoenergetic diets were prepared (Table 1), each as Starter-Grower and Finisher-ty- 
要

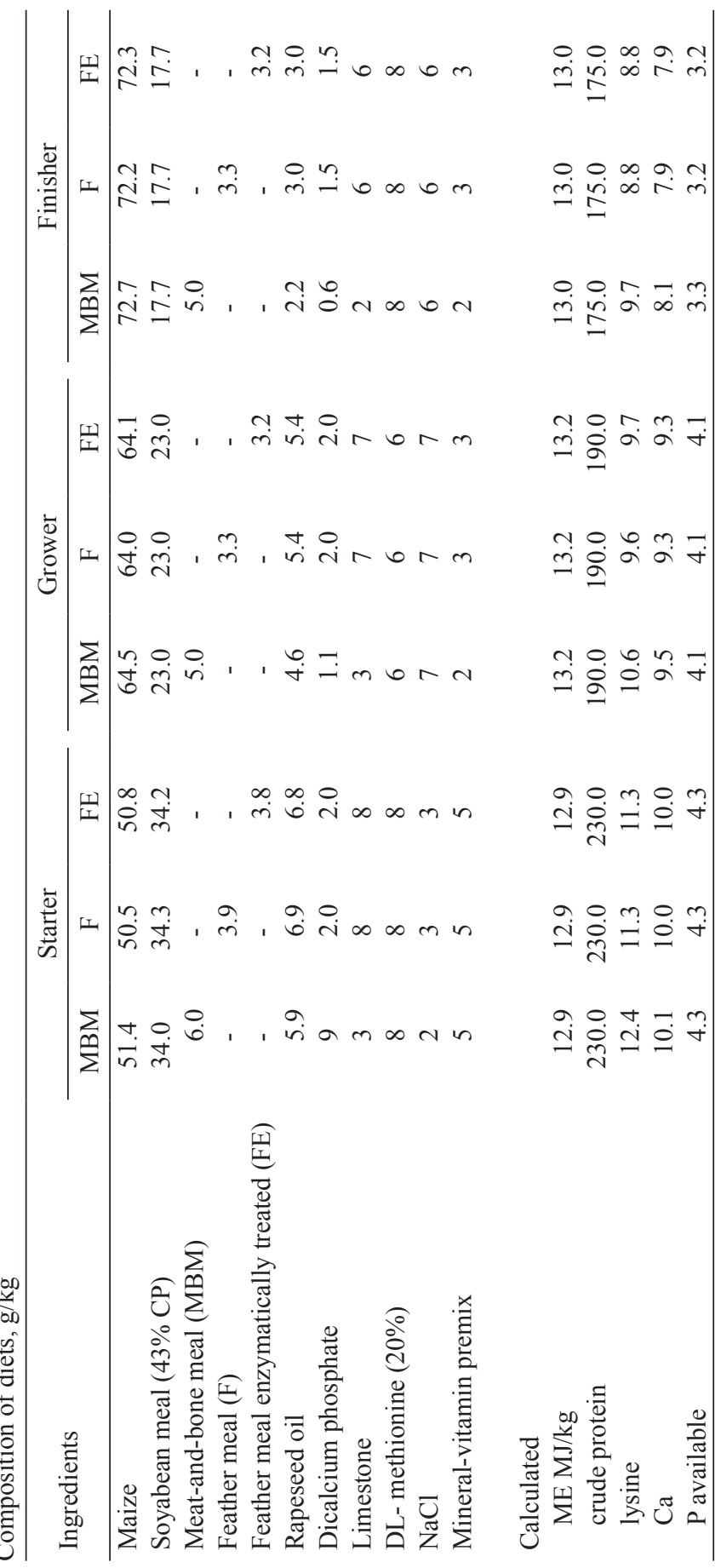


TABLE 2

The chemical composition $(\mathrm{g} / \mathrm{kg})$, in vitro protein digestibility $(\%)$ and amino acid composition $(\mathrm{g} / 16 \mathrm{gN})$ of the meat-and-bone meal (MBM), feather meal (F) and enzymatically treated feather meal (FE)

\begin{tabular}{lcrr}
\hline & MBM & F & FE \\
\hline Dry matter & 91.0 & 93.0 & 93.0 \\
Crude protein & 55.0 & 84.9 & 86.6 \\
Crude ash & 18.2 & 1.8 & 2.2 \\
Crude fat & 13.6 & 4.5 & 3.7 \\
In vitro digestibility of crude protein & 87.3 & 18.0 & 34.3 \\
& & & \\
Amino acid & & & \\
arginine & 7.1 & 6.3 & 6.6 \\
histidine & 1.9 & 1.1 & 1.3 \\
lysine & 4.9 & 2.2 & 2.1 \\
methionine & 1.3 & 0.4 & 0.4 \\
methionine + cystine & 2.2 & 4.8 & 4.0 \\
phenyloalanine + tyrosine & 6.2 & 7.3 & 6.8 \\
threonine & 3.1 & 3.8 & 4.3 \\
leucine & 5.6 & 6.8 & 7.0 \\
isoleucine & 2.7 & 4.0 & 4.0 \\
valine & 4.2 & 6.4 & 7.0 \\
\hline
\end{tabular}

pes. The control diet contained $60 \mathrm{~g}$ of meat-and-bone meal, in diets $\mathrm{F}$ and $\mathrm{FE}$ the respective feather meal substituted crude protein of the meat-and-bone meal from control group. Chickens were fed experimental diets ad libitum in mash form, from day 1 to 14 of life, Starter, from day 15 to 35, Grower, and from day 36 to 42, Finisher diets.

Feed intake and body weight were measured in weekly intervals, feed conversion ratio (FCR) and body weight gain (BWG) were calculated in each replication.

One-way analysis of variance was performed using SAS (1996) System ver. 6,12 . It was also used for single factor analysis. Differences were considered significant at $\mathrm{P} \leq 0.05$.

\section{RESULTS AND DISCUSSION}

The chemical composition of the diets is given in Table 2 .

In the tested feather meals no Salmonella sp., Staphylococcus sp., pathogenic Streptococcus sp. or Clostridium sp., were found.

In the starter period the best BWG was recorded in the control group. However, at the end of the experiment, the differences between groups were negligible (Table 3). 
TABLE 3

Performance of chickens

\begin{tabular}{lcccc}
\hline & \multicolumn{4}{c}{ Days of life } \\
\cline { 2 - 5 } & $0-14$ & $15-35$ & $36-42$ & $0-42$ \\
\hline Body weight gain, g & $347^{\mathrm{a}}$ & $1289^{\mathrm{b}}$ & $392^{\mathrm{b}}$ & 2030 \\
MBM & $340^{\mathrm{b}}$ & $1308^{\mathrm{a}}$ & $431^{\mathrm{a}}$ & 2080 \\
F & $325^{\mathrm{b}}$ & $1273^{\mathrm{b}}$ & $406^{\mathrm{b}}$ & 2005 \\
FE & 0.4 & 1.4 & 1.2 & 2.4 \\
Poled SEM & & & \\
Feed conversion ratio, kg feed/kg BW & $1.14^{\mathrm{a}}$ & 1.76 & $2.36^{\mathrm{a}}$ & 1.75 \\
MBM & $1.23^{\mathrm{b}}$ & 1.82 & $2.32^{\mathrm{a}}$ & 1.81 \\
F & $1.21^{\mathrm{b}}$ & 1.76 & $2.42^{\mathrm{b}}$ & 1.79 \\
FE & 0.02 & 0.01 & 0.04 & 0.02 \\
Poled SEM & & & & \\
Mortality, \% & 1.00 & 1.00 & 2.08 & 4.16 \\
MBM & 0.00 & 2.08 & 1.00 & 3.12 \\
F & 1.00 & 1.00 & 2.08 & 4.16 \\
FE & & & \\
\hline
\end{tabular}

MBM- meat-and-bone meal

F - feather meal

FE - feather meal enzymatically treated

a,b - mean values for BWG and FCR in a column with no common superscripts are significantly different at $\mathrm{P} \leq 0.05$

In the first two weeks of life, broiler chickens fed diets containing F and FE meals had inferior feed conversion ratio $(\mathrm{P} \leq 0.05)$ than birds from the control group; this is in agreement with our earlier findings (Rutkowski, 1988). Throughout the whole experiment those differences were not statistically significant (Table 3). Feather meals have also been used in laying hen (Koelkebeck et al., 1999) and turkey diets (Liu et al., 1989) with good results. However Bielorai et al. (1983) reported a decrease of BWG in broiler chickens fed diets containing feather meals. This might be caused by low digestibility of lysine in feather meals or its high $(15 \%)$ inclusion in the diet. The content of limiting amino acids in F and FE meals was similar. The first limiting amino acid was methionine, which was is in agreement with our earlier studies (Rutkowski, 1988), but was in contrast with the results of Kim and Patterson (2000) and Moritz and Latshaw (2001). Sulphur amino acids limit also the nutritional value of meat-and-bone meals (Wang and Parsons, 1997). In feather meal $\mathrm{F}$ the cystine level was higher than in the meat-and-bone meal, however, after treatment with Insta-Pro ${ }$, the content of this amino acid slightly decreased. This is in agreement with the results of Kim and Patterson (2000). Papadopoulus et al. (1985) and Moritz and Latshaw (2001) concluded that cystine is the most sensitive amino acid during feather processing. The enzymatic hydrolyzis of feather meal 
had a positive effect on in vitro digestibility of crude protein (Table 2), which is in agreement with the results of Kim and Patterson (2000). However, this was not reflected in the production parameters of broiler chickens. Also Bielorai et al. (1983) suggested that the value of the in vitro protein digestibility coefficient was not useful in the estimation of the nutritional value of the feather meal in broiler nutrition.

\section{CONCLUSIONS}

Feather meals may be used as components of broiler chicken diets in the Starter period in amounts up to $4 \%$ and in the Grower and Finisher periods, up to $3.3 \%$.

Enzymatic hydrolyzis did not affect the nutritional value of the feather meal even if the in vitro protein digestibility coefficient was higher than in the autoclaved feather meal.

\section{REFERENCES}

AOAC, 1997. Offical Methods of Analysis, Association of Official Analytical Chemists. 18 th Edition. Gaithersburg, MD

Bhargava K.K., O'Neil J.B., 1974. Composition and utilization of poultry by-products and hydrolyzed feather meal in broiler diets. Poultry Sci. 54, 1511-1518

Bielorai R., Harduf Z., Iosif B., Alumot E., 1983. Apparent amino acid absorption from feather meal by chicks. Brit. J. Nutr. 49, 395-399

Haque A.K.M.A., Lyons J.J., Vanderpopuliere J.M., 1991. Extrusion processing of broiler starter diets containing ground whole hens, poultry by-product meal, or ground feathers. Poultry Sci. 70, 234-240

Kim W.K., Patterson P.H., 2000. Nutritional value of enzyme- or sodium hydroxide-treated feathers from dead hens. Poultry Sci. 79, 528-534

Kim W.K., Lorenz E.S., Patterson P.H., 2002. Effect of enzymatic and chemical treatments on feather solubility and digestibility. Poultry Sci. 81, 95-98

Koelkebeck K.W., Parsons C.M., Leeper R.W., Jin S., Douglas M.W., 1999. Early postmolt performance of laying hens fed a low-protein corn molt diet supplemented with corn gluten, feather meal, methionine, and lysine. Poultry Sci. 78, 1132-1137

Liu J.K., Waibel P.E., Noll S.L., 1989. Nutritional evaluation of blood meal and feather meal for turkeys. Poultry Sci. 68, 1513-1518

Moran E.T. Jr., Summers J.D., Slinger S.J., 1966. Keratin as a source of protein for the growing chick. 1. Amino acid imbalance as the cause for inferior performance of feather meal and the implication of disulfide bonding in raw feathers as the reason for poor digestibility Poultry Sci. $45,1257-1266$

Mortiz J.S., Latshaw J.D., 2001. Indicators of nutritional value of hydrolyzed feather meal. Poultry Sci. 80, 79-86

Papadopoulos M.C., 1985. Amino acid content and protein solubility of feather meal as affected by different processing conditions. Neth. J. Agr. 33, 317-319 
Patterson P.H., Acar N., Coleman W.C., 1994. Feeding value of poultry by-product extruded with cassava, barley, and wheat middlings for broiler chicks: the effect of ensiling poultry by-product as a preservation method prior extrusion. Poultry Sci. 73, 1107-1115

Rutkowski A., 1988. Estimation of protein nutritive value using b coefficient test (TWb). I. Evaluation of proteins obtained from high protein feeds (in Polish). Zesz. nauk. Drob. 5, 31-41

SAS, 1996. SAS/STAT Users Guide (Release 6.12). SAS Institute Inc. Cary, NC (USA)

Wang X., Parsons C.M., 1997. Effect of processing system on protein quality of feather meals and hog hair. Poultry Sci. 76, 491-496

Webster A., Fletcher D.L., Savage S.I., 1996. Feather removal from spent hens up to 24 h post- mortem. J. Appl. Poultry Res. 5, 337-346

\section{STRESZCZENIE}

\section{Ocena przydatności enzymatycznie hydrolizowanego pierza dla kurcząt brojlerów}

Trzem grupom kogutków brojlerów, po 96 ptaków, utrzymywanych w klatkach po 8, podawano przez 6 tygodni diety zawierające: mączkę z pierza przygotowaną w sposób tradycyjny (F), mączkę poddaną procesowi hydrolizy enzymatycznej (FE) lub mączkę mięsno-kostną (MBM- kontrolna). Białko mączek z pierza lub MBM stanowiło około 14\% białka diet typu Starter i Grower oraz około $16 \%$ diet typu Finiszer. W pierwszych 2 tygodniach życia kurczęta żywione dietami zawierającymi mączki z pierza gorzej przyrastały i gorzej wykorzystywały paszę $(\mathrm{P} \leq 0,05)$ niż kurczęta z grupy kontrolnej. Po ukończeniu 6 tygodnia życia średnie przyrosty masy ciała wynosiły $2032 \mathrm{~g}$, a współczynnik wykorzystania paszy $1,8 \mathrm{~kg} / \mathrm{kg}$; nie stwierdzono istotnych różnic pomiędzy grupami. Skarmianie diety z mączką z pierza, poddaną hydrolizie enzymatycznej, nie wpłynęło na wyniki odchowu kurcząt mimo, że strawność białka tej mączki oznaczona in vitro była lepsza niż mączki nie hydrolizowanej. 